Portland State University

PDXScholar

Fall 2020

\title{
Interests and Priorities in Sockeye Salmon Management: How Are Policies Enacted and Interpreted on Three Alaskan Rivers?
}

Jake P. Palazzi

Portland State University

Follow this and additional works at: https://pdxscholar.library.pdx.edu/honorstheses

Part of the Aquaculture and Fisheries Commons, Environmental Studies Commons, Natural Resources and Conservation Commons, and the Natural Resources Management and Policy Commons Let us know how access to this document benefits you.

\section{Recommended Citation}

Palazzi, Jake P., "Interests and Priorities in Sockeye Salmon Management: How Are Policies Enacted and Interpreted on Three Alaskan Rivers?" (2020). University Honors Theses. Paper 937.

https://doi.org/10.15760/honors.960

This Thesis is brought to you for free and open access. It has been accepted for inclusion in University Honors Theses by an authorized administrator of PDXScholar. Please contact us if we can make this document more accessible: pdxscholar@pdx.edu. 
Interests and Priorities in Sockeye Salmon Management: How are Policies Enacted and Interpreted on three Alaskan Rivers?

By Jake Palazzi

An undergraduate honors thesis submitted in partial fulfillment of the requirements for the degree of Bachelor of Science in University Honors and Biology

Thesis Advisor Dr. Erin Shortlidge 


\begin{abstract}
The large export abundance of Alaskan salmon is well documented, and many studies have been performed to assess the economic and environmental viability of the industry and its management. Less research has been done to characterize how state intentions regarding fisheries allocation are conceived of by management or perceived by vulnerable groups in the user pool. This study seeks to qualitatively characterize the disconnect between state and Native Alaskan perceptions of management effectiveness, public interest, and Native Alaskan involvement using interviews. Results showed that Native Alaskan and state manager respondents had very different perceptions of management effectiveness and equity. When asked questions about the goals of policy and public participation in it, Native Alaskan respondents tended to identify issues of over-commercialized fishing and a lack of direct state acknowledgement of tribes while managers repeatedly referenced an equal public voice for all users and a focus on maximum sustainable yield. Results provide insight into the context certain policy decisions by the state of Alaska are received by Native Alaskan groups.
\end{abstract}

\title{
Introduction
}

Alaskan Natives face numerous difficulties passing legislation that will provide protection for their unique cultural and subsistence hunting and fishing needs. Some of the legislation which has been passed has been diluted to the point where it no longer fulfills its original purpose (Edwards \& Natarajan, 2008). Due to their lack of treaty rights like those afforded tribes in the lower 48 states, Alaskan natives face a unique situation regarding a lack of input in state subsistence management law in comparison to other groups (Krupa et. al., 2018).

This honors thesis seeks to shed light on the perceptions of fisheries management in Alaska through interviews from individuals involved in state management and Native Alaskan users. There are numerous key species, including commercially important Sockeye, King, and Chinook salmon stocks. 
Alaskan natives in the past have suffered from, among other things a lack of adequate recognition by the state (Alaska Admin. Order No. 125, 1991). This study is intended to help characterize the way management objectives are conceived of by the state and interpreted by Native Alaskan groups.

\section{Legislative Background}

The rights and provisions provided to Alaskan natives regarding lands and harvestable resources have long been a point of controversy in State and Federal courts. Since the United States purchased Alaska from Russia in 1867 there have been issues surrounding the inappropriate disbursement of lands rightly belonging to Native Alaskan peoples in residence within the state (Berardi, 2005). According to the ANCSA regional corporation, the original Russian claim to Alaskan land was under the laws of discovery, which state the two conditions under which aboriginal people may lose their lands: 1. Through a "just" war or 2. By giving up specific land in a treaty. No "just" war had caused the session of lands by Alaskan natives and Treaty making with Native tribes was terminated by congress in 1871 just a few years after the purchase of Alaska. Neither of the required conditions applied to the native people of Alaska at the time of purchase which left unresolved land claims when the purchase took place. The Alaska Federation of Natives (AFN) was formed in 1966 to combat land claims issues between the state and Alaskan Native groups. They were able to successfully lobby the Secretary of the Interior for a land freeze in 1966 which stopped land conveyances and selections that were taking place across the state and forced the State of Alaska and the federal government to resolve aboriginal land claims before they could continue.

In 1971 the Federal Government passed Alaska Native Claims Settlement Act (ANCSA). ANCSA took an approach to Alaskan aboriginal land claims that was unprecedented in the lower 48 states. The act extinguished aboriginal land claims in Alaska and instead established a for-profit model with land 
titles dispersed to 12 Alaskan Native corporations on Alaskan soil whose shareholders were native. The only Alaskan native group to opt out was the Metlakatla Indian community who instead chose to have the Annette Island reserve designated as a Federal Indian reservation.

With the passing of ANCSA Congress extinguished aboriginal hunting and fishing rights but provided no specific protections for subsistence in the act. The land allocated to the native corporations was not large enough to support hunting for subsistence purposes and did not include waters with fishing resources. Instead after the passage of the act Congress expressed an expectation that the State of Alaska and the Secretary of the Interior would work together to protect Alaskan native hunting and fishing needs. This was not accomplished. By 1978 the State of Alaska had enacted a law giving priority to subsistence uses of hunting and fishing resources over Sport, Commercial and Personal uses, however, the law defined all Alaskans to be subsistence users and did nothing to protect the Native Alaskan way of life.

In response, Congress passed the Alaskan National Interest Lands Conservation Act (ANILCA). The placed over 104 million acers of land in Alaska under Federal protected lands status and included a provision in Title VIII to give "rural Alaskans subsistence users" priority on Federal lands and waters. The language of "rural Alaskan subsistence user" was used rather than "native subsistence users" due to state objections.

To encourage compliance with Title VIII the state was given the option to manage subsistence uses on Federal lands as well as State and Private ones if the state Legislature adopted a law providing the same priority to "rural subsistence users". The legislature adopted a regulation in 1982 and then a statute 1986 that gave rural subsistence priority on state and private lands and by extension gave the state control over the same on federal lands. This statute was hotly contested by sport and commercial 
advocates who, after an unsuccessful ballot measure, brought it to the state supreme court who struck it down as unconstitutional in 1989.

Efforts to alter the constitution and adopt priority for rural subsistence use has been blocked in every session of the Alaska State legislature since 1990. Since 1992 a convoluted system in which the Federal government manages subsistence on federal lands and the State manages subsistence on State and Private lands. The Federal government provides priority the rural subsistence users while the State does not. The State Boards of Fish and Game create regulations on behalf of the state and Federal and Regional Advisory Boards create the regulations on federal land. This outcome is far from what was intended with the passage of ANILCA. 


\section{Cultural Background}

Fishing rights are integral to Alaskan native communities and cultures (Thornton,2001). Small rural groups of Native Alaskan peoples in Alaska have long lived off the land. Relying upon a mixed strategy of in situ and ex situ resilience strategies (Hoelting et. al, 2015). At times they relied upon the ability to adapt to natural abundance patterns through the harvesting of many different target species, and diversification of gear usage and trapping techniques. At other times they simply relied upon adaptive migration to move to new locations with un-exhausted fish and game resources when abundance fluctuated at customary locations (Himes-Cornell, 2014). Present-day Alaskan native fishing communities have much more rigid ties to certain locations due to increased governmental assistance programs including schools and sanitation (Berardi, 1999) and can no longer rely upon seasonal movement to combat declining resource abundance in waters around their communities. As such they have diversified harvest techniques and adapted to difficult circumstances with characteristic perseverance and skill.

The continued existence of subsistence communities such as those which exist in rural Alaska has been a puzzle to some who expect this way of life to die out with the influences of modernization and colonization. However, examination of the role subsistence plays in communities such as these show that, while it is a threatened way of life, it is a strong one and some communities have even experienced a resurgence of traditional techniques in recent years (Thornton, 2001). Subsistence fisheries are commonly defined in legislation as "local, non-commercial fisheries, oriented not primarily for recreation but for the procurement of fish for consumption of the fishers, their families, and community" (Berkes, 1988). However, the word subsistence can include cultural connotation beyond simply procuring the minimum resources required to feed oneself and family. Subsistence fishing can be defined as the act of fishing for survival, but to better understand the complex and deep culturally rooted relationship Native Alaskan groups have to subsistence one must consider the act to be one part 
of a more rich and complex traditional system. That system includes the way individuals gain prestige as fishermen, pass information on through generations, establish societal roles, and relate to the world around them (Schumann \& Macinko, 2006). In subsistence communities environmental knowledge is passed down through subsistence skill sets along with cultural and societal knowledge (Hoelting et. al., 2015). To cause their decline is to cause the decline of these Native Alaskan cultures. 


\section{Area of Study}

This study was performed using respondents from three key Sockeye baring rivers in Alaska: the Naknek, the Kenai, and the Copper.

\section{Naknek}

The Naknek river is part of the Bristol bay system which hosts the largest single sockeye run in the world.

Figure 1: Map of the Naknek River

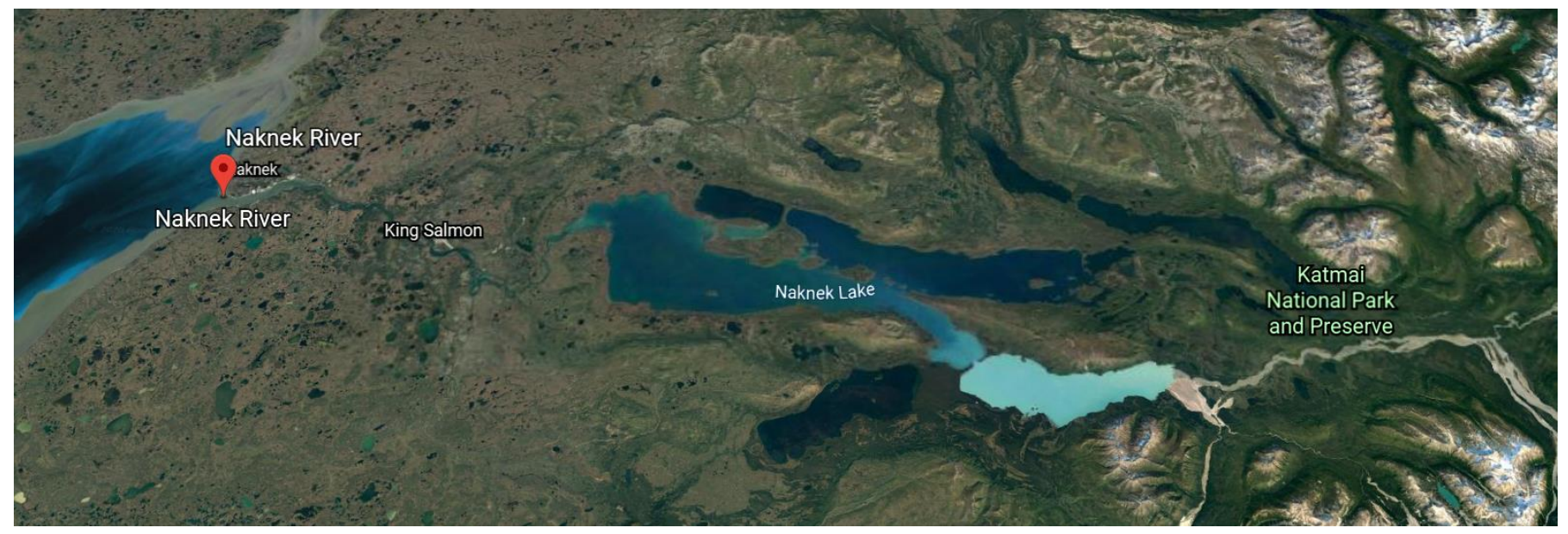

Fig. 1: Naknek River map (obtained from google maps)

The Bristol Bay watershed is made up of 6 major rivers: the Togiak, Nushagak, Kvichak, Egegik, Ugashik. These six rivers have a yearly average sockeye salmon return of 35.1 million fish of which the Naknek contributes close to 2 million annually. The Naknek river itself begins in Katmai National park and preserve. The river flows only 35 miles to the mouth of the bay with the town of King Salmon located at its head at the town of Naknek at its outflow. The Bristol Bay Borough is composed of the three towns on the river: Naknek, King Salmon and South Naknek. As of 2018 the entire population of the borough was 877 . The Bristol Bay Borough is composed of about $52 \%$ non-native and another $48 \%$ mix of Alaskan native cultures. Naknek as it is now grew up around the Russian Orthodox church which was the first entity to obtain land in the area after the treaty od cession in 1867. Much of the land the village 
is on now is made up of lots provided to homesteaders around the church. Currently 122 residents hold commercial fishing permits, but the industry is huge in Naknek. During fishing season several thousand people flood the area either to work in one of the 6 canneries on the river or crew and fish on the boats. All of Naknek lake, and by extent the sockeye spawning grounds are surrounded by Katmai national park and preserve. This park designation provides ample protection for fish rearing, as well as drawing record numbers of grizzly bears every season to feast on sockeye.

\section{Kenai}

Just south of Anchorage, and midway along Alaska's gulf coast, the Kenai river runs west from the glaciated Kenai mountains, and across the plateau of the Kenai lowlands before emptying into Cook inlet.

Figure 2: Map of the Kenai River

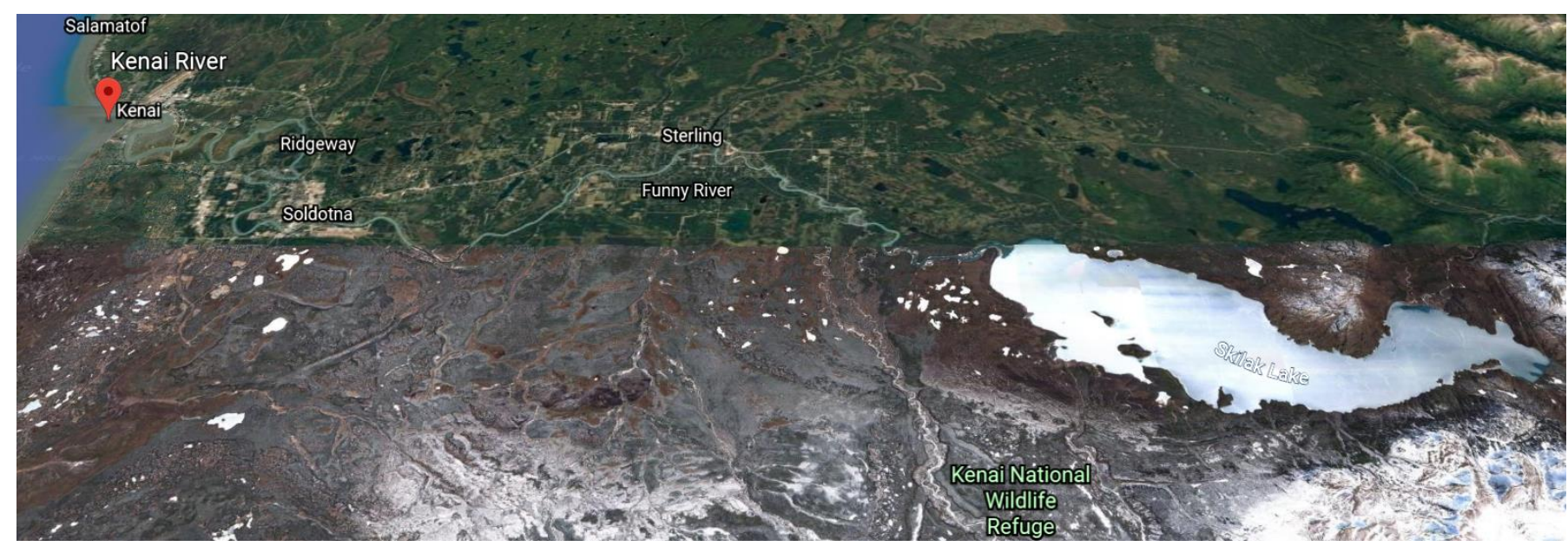

Fig. 2: Kenai River map (obtained from google maps)

The Kenai is part of the Upper Cook inlet Management area and averages close to 3.6 million sockeye salmon per season. The regional population around the river is close to 30,000 . Commercial fisheries on the Kenai river took off in the early 1940's. The united states had just engaged in WWII and certain domestic food products were extremely limited. The market space was filled by masses of Alaskan salmon. Massive amounts of fish were hauled in using drift netting and fish traps, setting the stage for 
the massive decline of fisheries in the Kenai in the 1950's. When Alaska became a state in 1959 the federal government handed over fisheries management to the state and new rules were implemented to halt stock decline in the Kenai. Throughout the 1960's and 70's the Kenai river was carefully managed to allow the return of its sockeye stock to previous abundance with increased data collection tracking salmon abundance and harvest rates as well as extremely restricted fishing. By the 1980's the fishery was back to pre-1940's abundance levels and the new Alaskan management was validated. In 1996 subsistence fisheries were closed in most of Cook Inlet and four Personal use fisheries open to all Alaskans were opened in their stead.

\section{Copper}

The Copper river is 290 -mile river in southcentral Alaska that flows out from a large region of the Wrangell, and Chugach mountains into the Gulf of Alaska.

Figure 3: Map of The Copper River

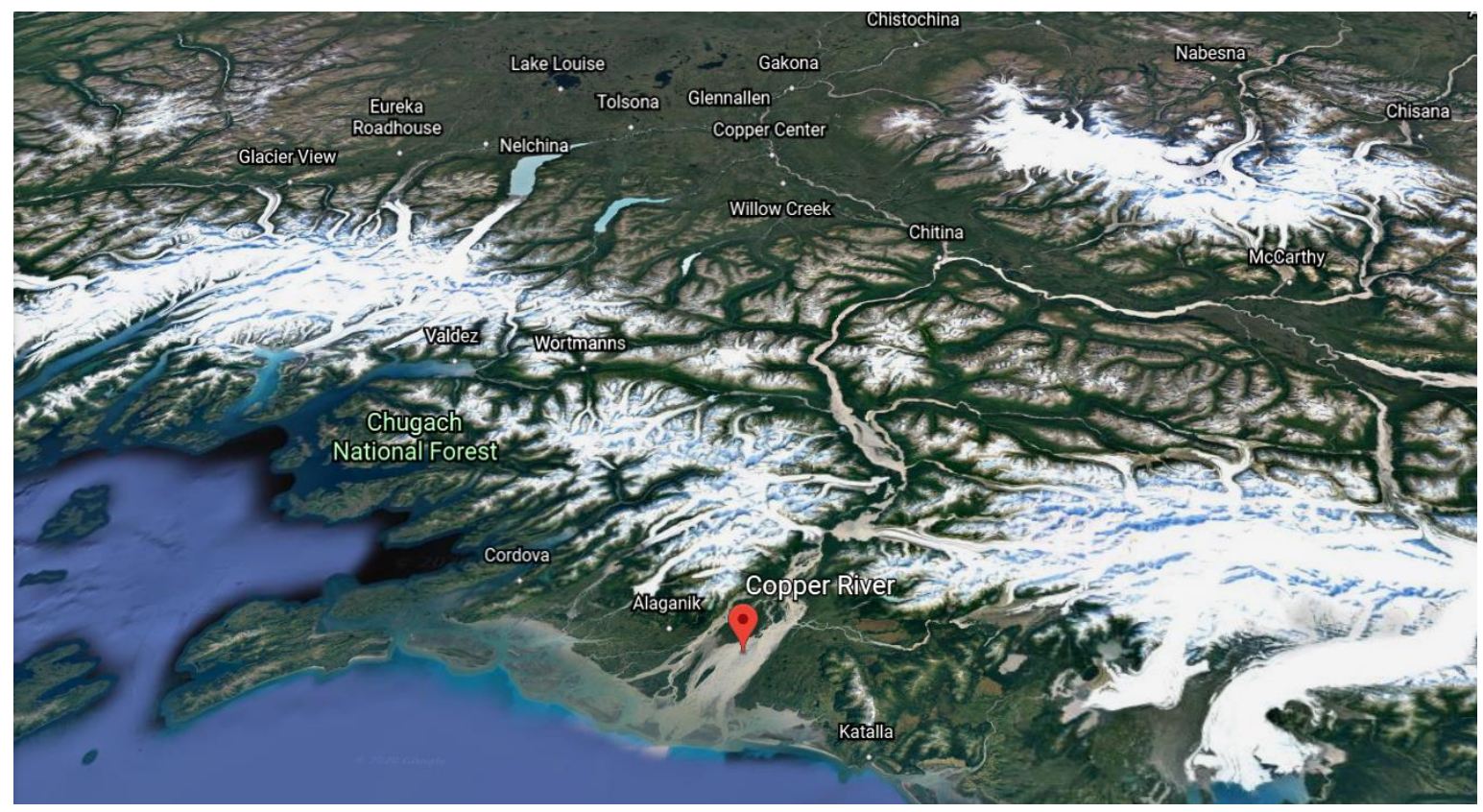

Fig. 3: Copper River Map (Obtained from Google Earth)

The Copper river has a seasonal run size of around 2.1 million wild sockeye, around 3,000 people live in the Copper river valley, and the population of Cordova, located near the mouth is close to 2,000 . The 
Copper River was traditionally fished by the Ahtna Athabascans. Today Copper river fisheries are still essential to Ahtna Culture, but the river is now almost entirely accessible by road. This has created massive competition between user groups. In the early 1900's a commercial fishery opened at the mouth of the copper river. There was an almost immediate issue with salmon abundance for the Ahtna people subsistence fishing upstream, and in 1918 federal regulations were passed to partially close the river to commercial fishing. Stocks remained depressed, and from 1924 to 1930 there was no commercial fishing permitted in the Copper river. Soon after statehood in 1959 Alaska imposed regulations on subsistence fisheries in the Copper that defined seasons, open areas, seasonal harvest limits, gear types, and rules on who could participate in the fishery. In the Early 1960's most of the subsistence harvest was dominated by fishwheel usage but by the late 1960's a larger dipnet subsistence fishery mostly operated by non-local urban residents, largely from Fairbanks opened up in a lower portion of the river just below Chitina to compete for fish. Problems with fishery abundance persisted in the 1970's and early 1980's and in 1978 the Alaskan legislature passed the state's first subsistence statute stating preference for subsistence fishing over other uses. In 1984 the Board of Fisheries decided to use rural residency as a standard for subsistence demarcation. As such many fishwheel operations by the Ahtna above Chitina were designated as customary and traditional use. They were given special protections, and subsistence permits for other parts of the river began to dry up. There is still massive competition for fish in the Copper river. 


\section{Methods and Materials}

This study was performed as part of the requirements for a senior undergraduate thesis at Portland State University. This study is intended to assess the opinions and perceptions of both Native Alaskan and state-based groups regarding the way in which fisheries management policy is implemented and interpreted in Alaska. I chose Sockeye salmon and management of sockeye fisheries as my study system for its harvest abundance in Alaska and the market price for wild caught salmon that it commands, second only to King salmon (Gilbertsen,2003). Overall wild caught Alaskan sockeye salmon makes up 65\% of wild salmon sold on global markets (Adkinson et. al, 2019) and from 2010 to 2013 Bristol Bay Alaska produced 31 to 45 percent of the global wild caught sockeye salmon harvest (Mcdowell Group, 2014).

With the massive amount of salmon coming from Alaskan sources "it can be argued that wild caught Alaskan sockeye influence worldwide market prices" (Adkinson et. al, 2019). As indicated above, the study rivers of the Naknek, Kenai and Copper all host sockeye fisheries of large economic and environmental importance to their local communities and the state as a whole. Due to the dual importance and likely differing perceptions, I sought to interview fisheries managers from the Alaska Department of Fish and Game as well as key fishing members of prominent Native Alaskan tribal groups. Interview participants from each river system (Naknek, Kenai, and Copper) were solicited for interviews. 


\section{Participant Selection}

Table 1: State Manager Respondents

\begin{tabular}{|l|l|l|l|}
\hline $\begin{array}{l}\text { Participant } \\
\text { Name } \\
\text { Pseudonym) }\end{array}$ & Job Title & Job Description & $\begin{array}{l}\text { Years of } \\
\text { Experience } \\
\text { with Salmon } \\
\text { Management }\end{array}$ \\
\hline Jack & $\begin{array}{l}\text { Commercial Fisheries } \\
\text { Manager }\end{array}$ & $\begin{array}{l}\text { Makes daily decisions on how to use the commercial fleet } \\
\text { based off fish abundance }\end{array}$ & 17 \\
\hline John & $\begin{array}{l}\text { Gillnet Area } \\
\text { Management Biologist }\end{array}$ & $\begin{array}{l}\text { Managing various sport and related fisheries and } \\
\text { management decisions to the public. }\end{array}$ & 15 \\
\hline Lawrence & $\begin{array}{l}\text { Sport Fish Area } \\
\text { Management Biologist }\end{array}$ & Managing sport, personal use, and subsistence fisheries & 46 \\
\hline George & $\begin{array}{l}\text { Sport fish Area } \\
\text { Management Biologist }\end{array}$ & $\begin{array}{l}\text { Sustained Yield Management of a Commercial Salmon } \\
\text { Biologist }\end{array}$ & 20 \\
\hline Charlie & Fishery. & \\
\hline
\end{tabular}

Table 2: Native Alaskan Respondents

\begin{tabular}{|l|l|l|l|}
\hline $\begin{array}{l}\text { Participant } \\
\text { Name } \\
\text { (Pseudonym) }\end{array}$ & Job Title & Job Description & $\begin{array}{l}\text { Years of } \\
\text { Experience } \\
\text { with Salmon } \\
\text { Management }\end{array}$ \\
\hline Lacey & Self-Employed & Artist and Commercial Fisherman & 24 \\
\hline Martha & $\begin{array}{l}\text { Tribal Shareholder } \\
\text { Advocate }\end{array}$ & Workforce development in an Alaskan Native Corporation & 40 \\
\hline Mary & $\begin{array}{l}\text { Intertribal resource } \\
\text { Commission } \\
\text { Executive Director }\end{array}$ & Traditional resource stewardship and advocacy & 40 \\
\hline Kyle & $\begin{array}{l}\text { Special Project } \\
\text { Manager at an } \\
\text { Alaskan Native } \\
\text { Corporation }\end{array}$ & $\begin{array}{l}\text { Meeting with legislators to discuss advocacy issues, Strategic } \\
\text { planning, program planning for policy proposals, and budget } \\
\text { production. }\end{array}$ & 30 \\
\hline
\end{tabular}

Fisheries managers from the ADFG were selected simply based on their management area. Each river was listed as having four or fewer managers responsible for its policy implementation, and some rivers had as few as one or two. Individuals with fishing experience from the Alaskan Native Alaskan 
tribal groups of Ahtna inc., Ahtna Intertribal Resource Commission, The Kenaitze Indian tribe, the Bristol Bay Native Association, and the United tribes of Bristol Bay were all contacted with requests for interviews. However, most Alaskan Native Alaskan respondents came either from contacts in Ahtna inc. or the Ahtna Intertribal resource Commission. To begin contact, key individuals listed on each organization's webpage were solicited via email with a request for interview. At the end of each interview the subjects were asked for additional contacts who might have pertinent fishing experience as well as direct association with Alaskan Native Alaskan groups in the area. Each of these individuals were in turn solicited via email with a request for interview until study saturation was reached. This study was approved under Portland State IRB \# (206985-18).

\section{Interview Collection and Coding}

The Zoom-based interviews lasted 45 minutes long on average. State manager interviews averaged 32 minutes long and interviews with Alaskan Native Alaskan contacts approximately an hour long. Each began with a review of interview consent and participant information sheets followed by a recorded consent statement. Prescreen questions concerning occupation description, and experience with sockeye fisheries management were either sent and returned by email before interview start, or asked before the study instrument, after the recorded consent statement. A study instrument with 5

open response questions regarding sockeye fisheries management and 2 Likert-type questions regarding fisheries economic and social importance to communities on each river was applied to all nine study participants. 
Table 3: Likert Scale Questions

\begin{tabular}{|l|l|l|}
\hline $\begin{array}{l}\text { Question } \\
\text { Number }\end{array}$ & Question Text & Scale \\
\hline 6 & $\begin{array}{l}\text { How would you rate the level of public } \\
\text { interest in preserving sockeye salmon } \\
\text { stocks on the river? }\end{array}$ & $\begin{array}{l}1-5,1 \text { very low interest, 2 moderately low } \\
\text { interest, 3 somewhat interested, 4 } \\
\text { moderately interested, and 5 extremely } \\
\text { interested }\end{array}$ \\
\hline 7 & $\begin{array}{l}\text { How would you rate the economic } \\
\text { importance of revenues from the catch of } \\
\text { sockeye salmon to communities on the } \\
\text { river? }\end{array}$ & $\begin{array}{l}1-5,1 \text { very unimportant, 2 moderately } \\
\text { unimportant, 3 somewhat important, 4 } \\
\text { moderately important, and 5 extremely } \\
\text { important }\end{array}$ \\
\hline
\end{tabular}

Each participant was given as much time as needed to answer each question, with some participants even providing long answers to the closed-ended questions after providing a numeric response. Each meeting recording was stored for transcription with identifiers removed. Transcripts were generated using online audio to text software Temi and then edited for errors in transcription. Transcript coding was performed through notes taken on hardcopy. First Each transcript was read through thoroughly. Since I was the interviewer and the coder, I had prior expectations of the themes and motifs that I expected to see in the text. I made note of those ideas and then chose 2 management and 2 Native Alaskan participants to closely read and begin to identify themes among all responses and between respondent groups. As I identified discrete ideas, I divided them into groups represented by their content or intent, and each of these groups were identified by short phrases that represented a code. I compiled these codes and subcodes into a code book. All interview transcripts were analyzed for unique ideas and with the developed codes in mind. Then each of these newly identified characteristics were sorted into code categories. After sorting, each code group was analyzed against the others to eliminate repetition, similarity, or idea nesting until the final codes used to analyze each transcript emerged. Codes were later presented in lab to gain group consensus and input on the 
identifiers used. Codes were used as a tool to identify the main ideas behind extensive open response interview answers and gain an idea of response patterns that could be drawn within respondent groups. 


\section{Results and Discussion}

Interview participants were either management professionals working for the state or Native Alaskans with experience in the fishing community. Both groups had unique takes on each of the study questions. Depending on group membership each question was interpreted to be in reference to different things.

\section{RQ1: How are sockeye management strategies selected and prioritized for implementation?}

Native Alaskan respondents tended to view questions about policy issues and management plans holistically with issues of recognition and representation in that policy; while state managers answers regarding policy issues consisted largely of the scientific monitoring framework behind existing plans and pre-determined triggers for different management actions. State managers, when asked this question, tended to discuss the abundance and escapement goals required to close or open fisheries and the historically harvest and spawning models used to establish those goals. No State manager except Lawrence mentions discussions with interest groups as a part of the strategy selection and implementation process:

"all throughout the year, we are meeting with the various user groups to talk over fisheries in season. It's a fairly constant flow of communication." (Lawrence, State Manager)

but later, even Lawrence says that management is largely based on achievement of escapement goals

"So, all of our management... is based on achievement of escapement goals. The escapement goals are based around the MSY (Maximum Sustainable Yield) principle." (Lawrence, State Manager). All other state managers fail to mention interest group consultation in their discussion of the creation and implementation of management policy. 
Jack: "as the fish come in, we, I can then kind of prescribe how much harvest pressure to put on it. As long as I maintain enough fish to achieve that year end escapement goal. The escapement goals are called biological escapement goals or sustainable escapement goals based on past year survival and production of fish per river." (Jack, State Manager).

John: "based on that consumptive use, we've got targets for escapement to ensure that we're meeting something close to maximum sustained yield for this overall management system." (John, State Manager).

Native Alaskan respondents on the other hand consistently expressed concerns regarding lack of issue recognition in management plans, transparency issues in policy explanations, and State authority disfunction when it comes to the implementation and creation of management policy. Martha spoke specifically about a federal to state policy disfunction caused by the management split of state vs federal lands in ANILCA:

"the state always likes to just say, if the feds are doing it, we don't need to, and then the feds will turn around and say, well, the state's taken care of it. We don't need to. And so, there's always like this gap in there, they, both of them don't want to overstep each other and take care of an issue. So, the state wants to focus on subsistence rights and not inhibiting anybody from being able to use their subsistence rights, but then there's federal laws that we all have to abide by also." (Martha, Native Alaskan).

Kyle focused on unequal usage and issues surrounding non-local pull on local management policy.

"So that total number of people that actually live on the copper river is less than 5,000 people. And then this massive urban fishery that comes in with 10 to 30,000 participants...has a very strong political presence. They control all the management policies that are set through the local advisory committee and through the board of fish process." (Kyle, Native Alaskan). 


\section{RQ2: What do you consider to be the main goals of sockeye salmon management?}

State managers predominantly reported that the goals of sockeye management related to maximizing salmon yield, while Indigenous managers responses were typically more holistic in nature. For example, Charlie, George, and Laurence all identified meeting escapement goals and providing user fishing opportunity as large goals of state-based management.

"Well, you know, at the hundred thousand foot level, it is maximum sustained yield and, and meeting the management, or the escapement goals to get there. So yeah, that, that is the number one priority." (Charlie, State Manager).

George similarly explained why sometimes aiming for both escapement and opportunity is a balancing act for management

"The other option that we have, we also have to provide opportunity. And so, sometimes we'll balance our main management decisions on that. So, this year was a great example. We had a very low Sockeye salmon run, so we balanced harvest opportunity with harvest amounts and tried to make sure we still stayed above the escapement goal, although we may have fallen behind it this year. We wanted to make sure we provide an opportunity as well." (George, State Manager).

Native Alaskan Respondents recognized sustainable abundance as a goal for all user and management groups on the river, though a consistent complaint throughout was a lack of effective and comprehensive management post-escapement. For example, Martha specifically highlights the lack of spawning ground monitoring by the state.

"they don't monitor any other areas where the spawning rivers and lakes are. They're concerned with how many are getting through, but they're not monitoring any areas to make sure that the fish are able to get to the spawning areas and able to spawn. And then that those spawn, those growing fish, are able 
to make it back to the ocean. There's no monitoring of any of that, except for how we feel as native people that have managed this land for 10,000 years. We're watching those." (Martha, Native Alaskan)

Martha was particularly concerned about the disconnect between the traditional ecological knowledge in her tribe and state management priorities. The traditional fishing practices of the tribe both Mary and Martha belong to depend upon allowing many harvestable fish go to increase spawning. Mary identified issues that she sees with the state managing to the minimum allowable escapement with stopgaps that might not have as large an effect as the state thinks going into the calculation.

"they're setting goals to the minimum escapement. When we talk with the in season manager here, they're looking at this, we know there's this many fish coming through the sonar, and we know that we need to account for, um, the stock that was introduced by the Gulkana hatchery or incubation unit. And so, we'll subtract that. And then we've got the subtraction of the subsistence use and personal use. And they're guessing at that, and then we've got sport fish. They try to manage to the minimum goal." (Mary, Native Alaskan).

Concerns surrounding the deviation of state management goals towards maximum harvest rather than sustainable fish reproduction were repeated throughout.

\section{RQ3: What do you consider to be the largest competing interest to sockeye salmon} management?

Native Alaskans identified User Group Competition and Early/Overfishing as major barriers to management. A repeating theme in the answers to this question was the Commercial dominated nature of fishing, which sometimes leads to overharvest. For example, Martha stated:

"we didn't have a first run this year. We did not get fish in our fish wheels until, June 15, because that first one either didn't come through or it came in really early, but we believe that the commercial 
fishermen actually caught those fish. And we didn't have a first run, which to us is a huge problem. That first run has got to get up there, do its thing. The second run comes, we get roughly five or six runs in a summer." (Martha, Native Alaskan)

Many Native Alaskans actually take part in commercial fisheries as well as subsistence for their own purposes, but the frustration expressed with competing for the same resource comes from the differential goals of commercial vs. subsistence management. Mary:

"commercial fisheries takes over 90\% of the, of the take, subsistence fisheries are like two or 3\%, I think, between personal use... I don't want to say that commercial Fisheries is, is a bad thing. I've had family that used to be commercial fishermen, but... the commercial fisheries are managed through department of commerce, not through department of natural resources or the department of fish and game. It makes a big difference in philosophy because it's all about income and not about the resource." (Mary, Native Alaskan).

State managers similarly identified competition between allocative groups as a central issue, though competition with management may not be an accurate representation of what they mean. Rather than a barrier to management success, user group competition seems to function for them as another problem solvable by management success. The competition appears to them to largely remain between the groups. For example, John says:

"Well, I mean, you've got allocative issues, um, between the user groups, for sure. Historically that's been the case for a long time. You've got your largest consumptive user base as the commercial, followed by the personal use and then a subsistence use in the fishery. That's not an order of priority by any means, but that's just the level of harvest annually and then the sport fishery is a minor component for Sockeye on the river. We definitely have some frustrations that are aired pretty regularly between the user groups." (John, State Manager) 
Issues arise when user groups perceive the allocation of fisheries resources as inequitable to all parties. While this is not necessarily a barrier to successful management, it is an issue that successful management attempts to address. John:

"The management is not perfect, you know, so that's probably when you're going to hear the most frustration between the groups is when they think that management actions in hindsight were inequitable. You know, we only have so much information. And so, there is, there's definitely aspects of that, that we have don't have as much control over as we'd like, but we'll do the best we can." (John, State Manager)

That said, many managers identified allocation issues as out of their wheelhouse, and not an issue meant to be solved by them. For example, Lawrence says:

" there may be competing interests within user groups, but we follow the allocation and that's sorted out at the board of fish, the department in no way takes part in the allocation, we keep our hands out of that, we just follow the plans, meet the escapement goals that the board handles." (Lawrence, State Manager)

\section{RQ4: How are Native Alaskan groups involved in the creation of management policy?}

State managers responded to this question most commonly with descriptions of the public proposal process that Alaska employs to introduce new management policy in fisheries, as well as references to Native Alaskan usage of subsistence fisheries permits. As described previously in the Policy Background section, there are no laws or statutes in the state of Alaska specifically protecting Native Alaskan hunting and fishing rights. The state constitution specifies that "Wherever occurring in 
their natural state, fish, wildlife, and waters are reserved to the people for common use." (Article $8 \S 3$. Common Use). In accordance with this mandate, as Lawrence says:

"For development of the plans, it's an equal process for everyone. The meetings are public. Anybody can submit a proposal to alter a plan or regulation, and anybody can attend the meeting. There are sections of the meeting that are set up just for public comment. And so that's the involvement, whether Native Alaskan or not everybody has an equal say when it comes to development of these plans. And that's just kind of a base, principle for the state is we do not provide preference nor differentiate between any specific groups. Every Alaska resident is considered equal when it comes to access to resources." (Lawrence, State Manager)

There are few regulations in place that specifically protect Native Alaskan fisheries usage, though there are laws in place to protect subsistence resource usage in state law, as George mentions:

"subsistence fishing in the state of Alaska has priority. So that's the last one to be regulated. And there there's an amount necessary for subsistence. So, if that number is not being met, then subsistence users can come in and ask for more fish and that would be allocated to them. That would come from somebody else. So, we'd have to cut back the other fisheries in order to provide for that increase. So, it's kind of a tradeoff situation. Native Alaskan don't have any more weight in that process than anybody else. Subsistence is open to all Alaskans, not just native Alaskans" (George, State Manager)

As George mentions, subsistence fishing permits are open to all Alaskans. However, there are no special considerations for the unique position subsistence fishing holds in Native Alaskan communities.

Native Alaskan respondents' answers to this question consistently included concerns regarding a lack of specific Native Alaskan recognition in policy, the struggle to prove to the state that Native Alaskan groups have knowledge to provide for sustainability, and repeated reference to the committed 
and repeated advocacy work of Native Alaskan interest groups and individuals in the public proposal process. For example, Kyle explains how Native Alaskan rights have been weakened in Alaska:

"they've taken any Native Alaskan, right, and diluted it down by, the McDowell decisions stating that any, Alaska resident can be eligible to be a subsistence fisherman. So basically, all your Native Alaskan rights, they're not eliminated. They're just diluted down to where they don't mean anything. So that's why I put the word subsistence. And a lot of people have as well, because the term has been co-opted at this point the word doesn't mean what it should." (Kyle, Native Alaskan)

Martha speaks about the lack of state recognition of traditional ways of knowing:

"I would characterize it as we're still trying to prove that we have knowledge to provide to them, the state agencies and federal government, um, back in the, when they first opened... they came to us to get that information. We have books from BLM and park service of our elders, taking them to these rivers and taking them to these areas and telling them what, where the fish were, how we're managing the fish. And then today they act like we don't know anything... they have forgotten that we have all this knowledge. So, we have several Native Alaskan communities fighting the system. We feel fighting the system because we're trying to prove that we deserve recognition for one thing." (Martha, Native Alaskan)

Mary, when asked this question, raised concerns regarding the effectiveness of indigenous advocacy and participation in the policy public proposal process:

"It's, very slanted as far as what comes from the department as to what comes from individuals or tribal organizations or other organizations. Not very many proposals get adopted that were submitted by individuals or, or tribal organizations. It's primarily the departments proposals and the, the larger commercial interest organizations that they look at. I don't know if it's a language difference, a 
vocabulary difference, or you know, um, how we submit proposals, but it's definitely not an equitable process." (Mary, Native Alaskan)

\section{RQ5: Given free reign, what would you change about sockeye management practices, and why} do you believe these changes have not been implemented?

When asked this question all state managers indicated no significant changes were necessary. Some participants mentioned increased funding for monitoring and research but on the whole managers identified no significant changes as necessary. John mentions the need for increased monitoring to differentiate between stocks as key:

"we're always short on stock assessment tool information, um, and that's just, you know, that's just the, just the nature of the system. It's hard to, to monitor salmon in a glacier turbid river system with more than a hundred different stocks. And then you've got copper river Delta stocks on the top of that, that all come into the mix. As I mentioned earlier genetics work, I think will, will help us quite a bit with that. We'll see some separation and these different stock reporting groups, which would be pretty interesting. And I think that's probably the next step that we'll see with management of stocks" (John, State Manager)

In season Alaskan commercial fisheries management is done through a well-oiled system. As indicated in John's interview excerpt above, any changes managers would make call for more effective monitoring to meet preexisting plans. Alaskan fisheries have seen massive commercial success. As mentioned in the methods section, wild caught Alaskan sockeye salmon makes up $65 \%$ of wild salmon sold on global markets (Adkinson et. al, 2019). This success has put faith in management's ability to perform effectively at an all time high. However, the contentious issues surrounding Alaskan fisheries 
have more to do with the creation of those same management allocation plans which have less to do with commercial success. Charlie explains:

"If I close the fishery, we can be closed for 10 days during what should be the peak of the run and people start calling, I just say, look, we don't have enough escapement, like, okay, thank you. I can hardly think of a situation where I said, well, we need to be closed to get more escapement. And somebody tried to argue. Everybody is bought into this management system here. It's worked for a long time. There are nuances in the fishery and decisions and things like that, people might have concerns with or something. But when it comes to making sure escapement comes first and making sure that we get those fish coming back into the future, no one will argue here, it's really amazing that way." (Charlie, State Manager)

The history of Alaskan fisheries is checkered with conflicts over access rights, and fishing declines and collapses (Loring, 2012). While Alaskan fisheries have been lauded as sustainable success stories (Hillborn et. al. 2006) not all Alaskans agree with that assessment. Native Alaskans responded to research question five with concerns that echo these. The most consistently referenced issue was a need for the establishment of Native Alaskan specific allocative fisheries. Kyle:

"the first thing I would do is I would establish a Native Alaskan fishing priority or re-establish fishing rights and allocate a percentage of the run to Native Alaskan people. Put that into the constitution or into a treaty or into a federal amendment... right now we have federal rules and which are for rural residents and we have state rules, which are for all Alaskans and then there's subsistence rules, which are state rules, which are for all Alaskans. And there's nothing for a Native Alaskan fishery." (Kyle, Native Alaskan) 
Many Alaskan natives have been disenfranchised by the switch to limited-entry quota-based fisheries management (Loring, 2012). As Martha states, the basic need is for state recognition of the deep and culturally based investment of Native Alaskans in fisheries management and sustainability.

"I don't know what I can necessarily change, except I'd like to change the attitudes of committees and the people we're talking to, you know, open their minds. We had the board of fish, maybe it was the board of game come here and actually have a meeting in our area... we asked them to come to our area. So, we at least show them around and show them what we do here. They hear from us all the time on what we're wanting, but they have no idea what kind of lives we live. So, I think more education to the, committees on how hard we're trying to help them manage, how much we want a seat at the table. We really should have our own committee that's that has as much weight as a local committee when we go to the end game of the board of fish." (Martha, Native Alaskan)

The struggle by Native Alaskans to be heard by the state in matters of resource division and management is well documented and stems from the removal of their hunting and fishing rights through Alaska Native Claims Settlement Act (Flanders, 1988) These rights were removed to prevent their use by Alaskan natives to claim land, and because the state of Alaska had assured the federal government that it could adequately protect them on its own (Flanders, 1988). Ever since the passage of the act Alaskan natives have struggled to have their voices heard by the state. 
RQ6: How would you rate the level of public interest in preserving sockeye salmon stocks on the

river?

RQ7: How would you rate the economic importance of revenues form the catch of sockeye salmon to communities on the river?

Both these questions were Likert-style rating questions (see Table 3).

Table 4: Question 6 results

\begin{tabular}{|llll|}
\hline & & $\begin{array}{l}\text { Answer } \\
\text { (Scale- Based) }\end{array}$ & \multicolumn{2}{l|}{$\begin{array}{l}\text { Mean for } \\
\text { Respondent Type }\end{array}$} \\
Native & Lacey & 5 & \\
Alaskan & Martha & 3 & \\
Respondents & Kyle & 5 & \\
\hline & Jack & 5 & \\
& John & 5 & \\
State & Lawrence & 5 & \\
Manager & George & 5 & \\
Respondents & Charlie & 5 & \\
& & 5 & \\
\hline
\end{tabular}

Table 4: Question 6 results: On a scale of 1-5 how would you rate the level of public interest in preserving sockeye salmon stocks on the river?

Table 6: Question 7 Results

\begin{tabular}{|c|c|c|c|c|}
\hline & & $\begin{array}{l}\text { Answer } \\
\text { (Scale -Based) }\end{array}$ & & $\begin{array}{l}\text { Mean for } \\
\text { Respondent Type }\end{array}$ \\
\hline & Lacey & & 5 & \\
\hline Native & Martha & & 2 & \\
\hline Alaskan & Mary & & 5 & \\
\hline Respondents & Kyle & & 5 & 4.25 \\
\hline & Jack & & 5 & \\
\hline & John & & 4 & \\
\hline State & Lawrence & & 5 & \\
\hline Manager & George & & 5 & \\
\hline Respondents & Charlie & & 5 & 4.8 \\
\hline
\end{tabular}

Table 6: Question 7 results: On a scale of 1-5 how would you rate the economic importance of revenues from the catch of sockeye salmon to communities on the river? 
The answers to question 6 indicate high levels of public interest in the preservation of salmon stocks. Martha was the only individual not to rate interest as a 5:

"That's a three, I mean, there's still people out there that are not users and our tribe. They eat fish, but they don't understand anything about it... the fish wheel is hard to manage. It's hard to keep running all that. So, if you don't have the energy for it or you don't know what you're doing, you're not going to do that." (Martha, Native Alaskan)

She references knowledge of the resource as key to investment in it. To be concerned with the preservation of salmon stocks, a certain level of involvement is required. She was also the only respondent to give a 2 rating for question 7 , referencing the fact that her tribe does not sell the fish they catch.

Overall response themes as compared between state managers and Native Alaskan fisheries users indicated that State managers viewed fisheries management and policy as unassociated with politics and decided by science, while Native Alaskan respondents viewed fisheries management as science affected by political aims, lacking key monitoring features and requiring more equitable representation. 
Table 7: Overall Response Themes

State Managers: Management policy as representative of public aims, and impartial and scientific

"I guess the overall [aim is] abundance-based management. We have escapement goals set for each river and actually for each species and sometimes several stocks of one species in a river, just depends on what's in there... as the fish come in, we can then prescribe how much harvest pressure to put on it. As long as I maintain enough fish to achieve that year end escapement goal." (Jack, State Manager)

"Well, for development of the plans, it's an equal process for everyone. Um, the meetings are public. Anybody can submit a proposal to alter a plan or regulation, and anybody can attend the meeting... whether indigenous or not everybody has an equal say when it comes to development of these plans." (Lawrence, State Manager)

"There's not much that I would change that I can think of... we already have escapement goal set. So, we have to adhere to those... We're guided by management plans and we have some leeway in there to, to adapt in season. But for the most part, we still have specific goals required to meet. So overall there's not a whole lot more that we can do." (George, State Manager)
Native Alaskans: Management policy as lacking indigenous input and determined by politics

"it's very slanted as far as what comes from the department as to what comes from individuals or tribal organizations or, um, other organizations...it's primarily the departments proposals and the, the, um, larger organizations... that they look at. It's definitely not an... equitable process.... The board of fish is primarily made up of commercial fishermen. There are no, in River people on that board, they're all commercial use or ocean-going users." (Mary, Native Alaskan)

"There's no way within the state system for a tribe to have direct input... in Alaska the tribes are just another member of the public. And not only that... they've taken any indigenous, right. And diluted it down by, by the McDowell decisions stating that any, any Alaska resident can be eligible to be a subsistence fisherman. Your indigenous rights are not eliminated. They're just diluted down to where they don't mean anything." (Kyle, Native Alaskan)

"I would characterize it as we're still trying to prove that we have knowledge to provide to them... today they act like we don't know anything... they have forgotten that we have all this knowledge. Um, so we have several indigenous communities fighting the system. We feel fighting the system because we're trying to prove that we deserve recognition for one thing." (Martha, Native Alaskan)

The data show an obvious disparity between the lens state management vs indigenous users view management policy and decision making. I interpret this disconnect to be indicative of the power differential and aim disparity between the two groups. In their interview responses regarding the creation of fisheries management policy Indigenous users consistently associated policy with the societal motivations they perceive behind it, while state managers interpreted policy as resultant of scientific monitoring. When asked about the goals of policy indigenous users identified the maximization of commercial take as a motivator while state managers identified prescribed management goals with which they judge the success of fisheries operation. The association of policy with politics by indigenous user can be explained by their lack of voice in its creation, they are acutely 
aware of the differences between the values it promotes and the values that they hold. Native Alaskans are motivated to manage for continued practice of the cultural and subsistence needs identified in the cultural background section above, while state managers are motivated to "manage for maximum sustained yield" (Lawrence, State Manager). 


\section{Conclusion}

There is much to learn about the ways Native Alaskans affect and perceive state-based resource management. The disparity shown here between state and Native Alaskan perceptions of process, goals, and justification behind management indicate a lack of effective interface between Native Alaskans and the state. The Native Alaskan policy environment in Alaska is unique to the rest of the united states. A lack of treaty governance, and the direct and uncircumspect removal of hunting and fishing rights as recognized through the government has created a legislative environment like no other. In other parts of the united states with similar allocation issues, such as Washington state, landmark court cases like The Boldt decision, upholding agreements based on treaty rights and free, prior, and informed consent, established resource allocation percentages specifically for federal recognized tribal groups and gave them a say in the management process (Bruun, 1982). The Alaska Native Claims Settlement Act extinguished aboriginal land claims in Alaska, and by extent hunting and fishing rights for many native Alaskans at their customary locations. This was a major departure from previous legislation regarding tribal groups (Berardi, 2005). Disagreements between Native Alaskan and state respondents as to the goals, and priorities of management in these sockeye baring rivers in Alaska reflect the climate of allocative discord which the current overlap of state and federal fishing management in Alaska promotes. This paper's findings showed a much higher awareness by Native Alaskans of the political process behind policy creation and enactment than was recorded in the responses of state managers. This disconnect should not be viewed as systematic and unavoidable but rather as the indications of an avenue for management change. When issues such as these are identified, the system of government and the public process which creates that system must be analyzed as a possible source of the disconnect. Where discrepancies between state intention of management and its execution are found, solutions that allow for vulnerable groups to be heard and cultural protection advocacy to succeed must be produced. This will allow for more robust, effective, and trusted management to take place. This 
research serves as a preliminary steppingstone to assist in identifying the concerns surround public fisheries management in Alaska. However, more research from diverse disciplinary areas is needed to concretely characterize allocative discrepancies, user group competition, the effectiveness of monitoring, and the level of input Native Alaskan groups receive in public policy. Moreover, future research should seek to better understand how Native Alaskans engage in conceiving and implementing cultural knowledge-based management schema in their accustomed fishing locations. The system used, of community information gathering, group advocacy, public process participation, and cultural resource usage to conceive of and effect management change for the betterment of their communities and the enrichment of their culture is unique, and should be accommodated by state organizations that proport to manage for the good of the public. 


\section{Bibliography}

Edwards, Wayne, and Tara Natarajan. "ANCSA and ANILCA: Capabilities Failure?." Native Studies Review, vol. 17 , no. 2 , 2008, pp. 1-29.

Loring, Philip A., et al. "Local Perceptions of the Sustainability of Alaska's Highly Contested Cook Inlet Salmon Fisheries." Society \& Natural Resources, vol. 27, no. 2, 2013, pp. 185-199., doi:10.1080/08941920.2013.819955.

Gordon, Heather Sauyaq Jean. Self-Determination, Sustainability, and Wellbeing in the Alaska Native Community of Ninilchik. 2019.

Thornton, Thomas F. "Subsistence in Northern Communities: Lessons from Alaska." The Northern Review, vol. 23, 2001, pp. 82-102. Summer 2001.

Himes-Cornell, Amber, and Kristin Hoelting. "Resilience Strategies in the Face of Short- and Long-Term Change: out-Migration and Fisheries Regulation in Alaskan Fishing Communities." Ecology and Society, vol. 20, no. 2, 2015. Jun 2015.

Package-Ward, Christina, and Amber Himes-Cornell. "Package-Ward, C., and A. Himes-Cornell. 2014. Utilizing Oral Histories to Understand the Social Networks of Oregon Fishermen in Alaska." Human Organization, vol. 73, no. 3, ser. 2014, 2014. 2014.

Berardi, Gigi. "Schools, Settlement, and Sanitation in Alaska Native Villages." Ethnohistory, vol. 46, no. 2, pp. 329-359. Spring 1999.

Berkes, Fikret. "Subsistence Fishing in Canada: A Note on Terminology." Arctic, vol. 41, no. 4, 16 June 1988, pp. 319-320. December 1988. 
Schumann, Sarah, and Seth Macinko. "Subsistence in Coastal Fisheries Policy: What's in a Word?" Marine Policy, vol. 31, no. 6, pp. 706-718. November 2007.

Krupa, Meagan Boltwood, et al. "Resurrecting the Public Record: How to Assess Stakeholder Participation in Fisheries Governance." Marine Policy, vol. 96, pp. 36-43. October 2018.

Schwoerer, Tobias, et al. "Aquatic Invasive Species Change Ecosystem Services from the World's Largest Wild Sockeye Salmon Fisheries in Alaska." Journal of Ocean and Coastal Economics, vol. 6, no. 1. June 2019.

Gilbertsen, Neal. "The Global Salmon Industry (And It's Impacts in Alaska)." Alaska Economic Trends. October 2003.

Loring, Philip A. “Alternative Perspectives on the Sustainability of Alaska's Commercial Fisheries." Conservation Biology, vol. 27, no. 1. February 2017.

Hilborn, Ray, et al. "Fishing Rights or Fishing Wrongs?" Reviews in Fish Biology and Fisheries, vol. 15, ser. 2005, pp. 191-199. 2005.

Flanders, Nicholas E. "Native American Sovereignty and Natural Resource Management." Human Ecology, vol. 26, ser. 1988, pp. 425-449. 1988.

Bruun, Rita. The Boldt Decision: Legal Victory, Political Defeat. Publisher Not Identified, 1981.

Berardi, Gigi. "The Alaska Native Claims Settlement Act (ANCSA) - Whose Settlement Was It - An Overview of Salient Issues." Land Resources \& Envtl. L., vol. 25, ser. 2005, p. 131. 2005. 